\title{
PENGEMBANGAN BUKU CERITA TENTANG DESA TENGANAN DAUH TUKAD UNTUK MENINGKATKAN LITERASI BUDAYA SISWA KELAS V SEKOLAH DASAR
}

\author{
I.K. Nudina ${ }^{1}$, I.B.P. Arnyana ${ }^{2}$, I.B.P. Mardana ${ }^{3}$ \\ ${ }^{123}$ Program Studi Pendidikan Dasar \\ Universitas Pendidikan Ganesha \\ Denpasar, Indonesia \\ e-mail: nudina@undiksha.ac.id ${ }^{1}$, putu.arnyana@undiksha.ac.id ${ }^{2}$, \\ putu.mardana@undiksha.ac.id ${ }^{3}$
}

\begin{abstract}
Abstrak
Penelitian ini bertujuan untuk mengembangkan buku cerita tentang Desa Tenganan Dauh Tukad sebagai buku pelengkap pembelajaran untuk meningkatkan literasi budaya siswa kelas $\mathrm{V}$ Sekolah Dasar. Penelitian ini menggunakan model pengembangan ADDIE yang terdiri dari 5 langkah, yaitu analyze (analisis), design (desain), development (pengembangan), implementation (implementasi) dan evaluation (evaluasi). Namun, karena pandemi covid 19 maka pengembangan hanya pada tahap implementasi saja. Subjek pengembangan ini adalah 3 ahli (materi dan media), 3 orang guru dan 25 orang siswa kelas $\mathrm{V}$. Data dari ahli digunakan untuk menguji validasi buku cerita,data dari guru untuk menguji kepraktisan buku cerita dan data dari siswa untuk menguji efektivitas buku cerita. Instrumen penelitian mencakup: lembar penilaian materi pelajaran dalam buku cerita, lembar penilaian materi buku LORI, lembar penilaian media LORI, kuesioner kepraktisan dan tes hasil belajar. Data yang diperoleh dianalis dengan formula Gregory, formula Lawshe dan rata-rata. Hasil penelitian menunjukan 1) produk berupa buku cerita valid baik secara materi maupun media, 2) produk berupa buku cerita sangat praktis dan 3) produk berupa buku cerita terkategori efektif.
\end{abstract}

Kata Kunci : Buku Cerita; Literasi Budaya; Pengembangan

\begin{abstract}
This research aims at developing story book about Tenganan Dauh Tukad Village as supplementary book to improve the fifth grade students cultural literacy. This research applied ADDIE development model consisting of 5 stages, namely : analysis, design, development, implementation and evaluation. However, because of Covid 19 pandemic, tis research was finished until implementation stage. The subject consisted of 3 experts, 3 teachers and 25 students. Data from the experts were used for validation test, data from teachers were for practicality test, and data from students were for effectiveness test. to collect data, 5 instruments were needed, namely : learning materials assessment sheet, book material assessment sheet by LORI, media assessment sheet by LORI, practicality questionnaire, and students' achievement test. The obtained data were analyzed by using Gregory formula, Lawshe formula dan mean. The result of analysis shows that a) the developed story book was valid both for materials and media,b) the devloped story book was practical,and c) the developed story book was effective.
\end{abstract}

Keywords : Story Book; Cultural Literacy; Development

\section{PENDAHULUAN}

Pendidikan merupakan salah satu faktor yang sangat penting dalam menentukan tingkat kemajuan suatu negara. Untuk itu, mempersiapkan pendidikan yang berkualitas bagi generasi bangsa adalah hal wajib yang harus dilakukan oleh pihak-pihak terkait khususnya pemerintah dan guru. Mereka harus menyiapkan pendidikan yang tidak hanya membuat manusia pintar, tapi juga mampu menjadi jati diri bangsa dengan budaya-budaya Indonesia yang adi luhung. Menurut Wigianto (2015), 
pendidikan seharusnya mampu mencetak peserta didik agar memiliki kepribadian, moral dan karakter demi menjawab segala tantangan zaman.

Pemerintah merealisasikan ini dengan memperbaharui kurikulummenjadi Kurikulum 2013. Mulyasa (2013) menjelaskan bahwa kurikulum 2013 berbasis karakter dan kompetensi yang mewajibkan anak untuk aktif dalam pembelajaran. Melalui kurikulum ini, pengaplikasian pembelajaran pada satuan-satuan pendidikan dasar hendaknya didasari pada budaya lokal tiap-tiap daerah. Hal ini mengingat kemajemukan yang terdapat di Indonesia, di mana pada tiap daerah diperkaya pada ke-khasan dan keunikannya tersendiri. Keragaman budaya lokal hendaknya menjadi bahan pembelajaran dan pengembangan anak dalam berliterasi (Syamsiah, 2020). Nilai-nilai kearifan lokal yang harus tetap dipelihara dan dilestarikan melalui materi pembelajaran di sekolah.

Dengan penyajian budaya lokal pada pembelajaran maka diharapkan siswa menjadi senang membaca sehingga terjadi gerakan literasi budaya. Literasi adalah kemampuan berbahasa yang dimiliki seseorang dalam berkomunikasi "membaca, berbicara, menyimak dan menulis", dengan cara yang berbeda sesuai dengan tujuannya. Ini berarti, dengan literasi budaya, siswa membaca dan memahami banyak hal tentang budaya yang dipelajari. Dengan demikian, siswa dapat mencapai tujuan pemerintah melestarikan budaya.

Namun berdasarkan hasil observasi pada SDN 27 Pemecutan di Denpasar, melalui wawancara pada guru-guru kelas V SDN 27 Pemecutan di Denpasar dan juga pada beberapa guru kelas $V$ Sekolah Dasar segugus IV RA Kartini pada tanggal 10 Maret 2021. Ditemukan berbagai permasalahan dalam proses pembelajaran. Rendahnya tingkat literasi budaya pada siswa. Hal ini disinyalir karena keterbatasan materi pembelajaran literasi budaya yang disajikan pada buku pelajaran siswa kelas V Sekolah Dasar. Penelitian dalam hal ini pada buku Pelajaran Kelas V SD pada Tema 8, Sub
Tema 2, Pembelajaran 3 tentang "Desa Unik Di Bali", yang termasuk kategori pembelajaran literasi budaya.

Para guru tidak mampu mengembangkan pelajaran literasi budaya. Literasi budaya siswa di sekolah sangat rendah. Hal ini karena tidak adanya media pelengkap pembelajaran yang tepat. Kurangnya media pembelajaran berupa buku cerita yang memuat pengembagan pengetahuan literasi budaya siswa. Media pelengkap pembelajaran yang diharapkan adalah media yang menarik dan diminati oleh siswa (Arsyad, 2009). Sementara buku pelajaran atau buku pelajaran yang ada kurang tersaji dengan menarik bagi siswa. Pembahasan materi pada buku pelajaran sangat minim, juga tidak disertai dengan gambar-gambar yang dapat menarik minat dan perhatian siswa. Hal ini merupakan kelemahan buku pelajaran yang ada.

Hal lain yang ditemukan adalah minimnya budaya literasi siswa di sekolah. Siswa tidak gemar membaca. Kebiasaan membaca pada siswa belum terbangun. Perpustakaan sekolah sebagai pra sarana belajar literasi menjadi tempat yang jarang mendapat kunjungan rutin siswa. Sarana belajar seperti buku-buku penunjang pada perpustakaan sekolah terbatas jumlahnya, juga rendahnya pengetahuan siswa dalam berbagai hal yang bersifat budaya lokal, nasional maupun internasional terjadi akibat kurang membaca. Kesimpulannya bahwa tingkat literasi budaya siswa atau pengetahuan siswa terhadap budaya, apalagi pada budaya lokal sangat rendah.

Lebih lanjut, hasil studi pustaka untuk mengkaji cakupan materi literasi budaya pada buku pelajaran kelas $\mathrm{V}$ Sekolah Dasar. Peneliti berfokus pada buku pelajaran Tema 8 Lingkungan Sahabat Kita, Sub Tema 2 Perubahan Lingkungan, Pembelajaran 3 Desa Unik di Bali, yang memuat konten literasi budaya bagi siswa. Pada tema ini ditemukan keterbatasan dan keminiman informasi yang disajikan melalui buku pembelajaran. Materi literasi budaya lokal kepada siswa tidak dikembangkan secara mendalam. Hal ini menyulitkan bagi para guru untuk melakukan proses pembelajaran juga menyulitkan para siswa dalam menyerap 
pengetahuan tentang literasi budaya. Literasi budaya lokal yang seharusnya menjadi perhatian untuk diketahui dan dipelajari siswa kurang maksimal diterima melalui penyajian materi yang minim tersusun berdasarkan kurikulum yang ada saat ini.

Berdasarkan permasalahan yang ditemukan melalui wawancara maupun studi pustaka tersebut Peneliti berupaya mengembangkan hal yang dapat menjawab tantangan permasalahan di atas. Penelitian dalam bidang pengembangan media pelengkap pembelajaran literasi budaya ini penting dilakukan mencegah rendahnya pembelajaran literasi budaya pada siswa kelas $\mathrm{V}$ sekolah dasar. Jika hal ini tidak dapat ditingkatkan akan berdampak negatif ke depan bahwa siswa dan generasi masa mendatang tidak kenal budaya lokalnya, tidak memahami budayanya dan bahkan tidak mampu memelihara dan melestarikannya. Dampak terbesar adalah bahwa nilai-nilai luhur yang diwariskan oleh nenek moyang bangsa Indonesia akan semakin luntur menuju kepunahan. Sementara seharusnya sikap, perilaku, budi pekerti dan bahkan adab bangsa didasari pada nilai-nilai yang diwariskan oleh leluhur pendahulu kita.

Upaya dilakukan melalui pengembangan media buku cerita sebagai pelengkap pembelajaran. Buku cerita anak sebagai pelengkap pembelajaran dengan materi literasi budaya, guna menjawab tantangan masalah atas minimnya pengetahuan literasi budaya siswa. Buku cerita anak juga dihadirkan untuk membantu siswa meningkatkan minat membaca para siswa.

Untuk siswa kelas tinggi, yakni antara kelas IV hingga kelas VI Sekolah Dasar, terdapat karakteristik tersendiri yang cukup menonjol. Terlihat beberapa di antaranya adalah adanya minat terhadap kehidupan praktis sehari-hari yang konkrit, realistik serta memiliki rasa ingin tahu dan ingin belajar yang tinggi. Ketertarikan siswa pada "belajar" dan rasa "ingin tahu" ini tidak akan berkembang tanpa dorongan pihak pendidik ditambah ketersediaan "bekal" belajar dan pengembang "rasa ingin tahu" siswa tersebut. Dalam usia ini siswa tidak hanya ingin mengetahui dunia belajar sebatas buku-buku pelajaran saja, namun ada begitu banyak tanda tanya di kepala siswa yang ingin terjawab lewat materi-materi non pelajaran lainnya, seperti wawasan lokal, wawasan nasional dan internasional, dunia seni, dunia kebudayaan, dunia iptek dan berbagai hal lainnya. Dituntut terpenuhinya kebutuhan literasi penunjang kebutuhan siswa kelas tinggi Sekolah Dasar tersebut.

Sebagai bahan penelitian, ditemukan buku pelajaran yang tersusun berdasarkan kurikulum $\mathrm{K}-13$ telah menyerap nilai-nilai kearifan lokal tiap-tiap daerah di Indonesia dan menyajikannya dalam berbagai bidang studi, akan tetapi penyajian materi tidak secara luas dan mendalam. Materi hanya disajikan dengan ringkas dan sederhana, sebatas pengenalan. Penelitian ini mengangkat pembelajaran Kelas $\mathrm{V}$ SD pada Tema 8 "Lingkungan Sahabat Kita" Sub Tema 2 "Perubahan Lingkungan", Pembelajaran 3 "Desa Unik di Bali" sebagai pelajaran literasi budaya siswa. Ada 3 Desa Unik di Bali yang dipelajari dalam materi ini, yakni Desa Trunyan, Desa Penglipuran dan Desa Tenganan. Peneliti mengangkat pengembangan terhadap salah satu desa, yakni Desa Tenganan.

Desa Tenganan terletak pada bagian timur Bali di Kabupaten Karangasem Bali, tepatnya pada Kecamatan Manggis. Desa Tenganan terdiri dari 2 (dua) desa yang saling berdekatan dengan keunikan dan tradisi yang hampir sama, yakni Desa Tenganan Dauh Tukad dan Desa Tenganan Pegrisingan. Peneliti memfokuskan pada berbagai keunikan tradisi dan budaya pada Desa Tenganan Dauh Tukad. Untuk itu, potensi desa ini dapat dikembangkan menjadi buku cerita agar lebih menarik bagi siswa sebagai media pembelajaran.

Cerita anak merupakan suatu karya berupa karangan yang bertutur tentang suatu pengalaman, perbuatan atau kejadian yang ceritanya ditujukan untuk anak dengan gaya bahasa yang sederhana namun kompleks serta komunikatif dan mengandung nilai moral yang baik bagi anak. Untuk itu dalam 
pengembangannya penyusunan buku cerita perlu memperhatikan karakteristik sesuai kebutuhan usia anak.

Melalui penelitian ini, dikembangkan media berupa buku cerita tentang Desa Tenganan Dauh Tukad untuk Meningkatkan Literasi Budaya Siswa Kelas V Sekolah Dasar. Buku dibuat dengan judul "Petualangan Daring $\mathrm{Ke}$ Desa Adat Tenganan Dauh Tukad". Buku tersebut dibuat dengan memperhatikan karakteristik siswa kelas tinggi, memperhatikan kelayakan isi, kelayakan bahasa, kelayakan penyajian dan kelayakan kegrafikan yang sesuai tingkat penyerapan siswa kelas V Sekolah Dasar. Media buku ini juga dapat menjadi stimulan minat membaca anak. Pengoptimalisasian pembelajaran di sekolah melalui buku cerita sebagai pelengkap pembelajaran hendaknya mampu meningkatkan literasi budaya siswa, meningkatkan pengetahuan siswa terhadap budaya lokal daerahnya, serta sebagai sarana pelestarian budaya lokal di tiap-tiap daerah di Indonesia. Selain itu, Penelitian buku ini juga sebagai upaya meningkatkan kebiasaan membaca pada siswa.

\section{METODE}

Penelitian ini merupakan penelitian pengembangan dengan model ADDIE yang merupakan singkatan dari Analysis (analisa), Design (rancangan), Development (pengembangan), Implementatian (penerapan), Evaluation (evaluasi). Namun penelitian ini hanya sampai pada tahap implementasi saja. Subjek penelitian ini berjumlah 31 orang. Mereka terdiri dari 3 dosen ahli, 3 guru kelas $\mathrm{V}$ dan 25 siswa kelas V. Untuk mengumpulkan data, instrumen diperlukan mencakup lembar penilaian materi pelajaran dalam buku cerita, lembar penilaian materi buku dengan learning object review instrument (LORI), lembar penilaian media LORI, kuesioner kepraktisan dan tes hasil belajar. Setelah data dikumpulkan selanjutnya dianalisis dengan formula Gregory, Lawshe dan menghitung rata-rata yang dikonfirmasi ke dalam skala sebagai berikut.
Tabel 1. Skala Kategori

\begin{tabular}{cl}
\hline \multicolumn{1}{c}{ Nilai } & \multicolumn{1}{c}{ Kategori } \\
\hline $4,20 \leq \bar{X} \leq 5,00$ & Sangat Tinggi \\
$3,40 \leq \bar{X}<4,20$ & Tinggi \\
$2,60 \leq \bar{X}<3,40$ & Cukup Tinggi \\
$1,80 \leq \bar{X}<2,60$ & Rendah \\
$1,00 \leq \bar{X}<1,80$ & Sangat Rendah \\
\hline & (Mardapi, 2008)
\end{tabular}

Terakhir, untuk menghitung efektivitas produk, siswa diberikan tes yang terdiri dari 10 butir soal dimana 5 butir soal PPKn dan 5 butir soal Bahasa Indonesia. Sebelum digunakan dilakukan uji coba tes dan hasilnya semua butir valid. Selanjutnya diauji reliabilitas tes dan menunjukan nilai reliabilitas tinggi. Dengan demikian tes dapat digunakan mengukur efektivitas produk.

\section{HASIL DAN PEMBAHASAN}

Hasil penelitian dan pembahasannya dapat dibagi empat bagian sesuai dengan jumlah rumusan masalah. Secara rinci dapat disajikan sebagai berikut.

\section{Validitas Buku Cerita}

Validitas buku sebagai pelengkap pembelajaran yang dikembangkan dengan melakukan analisis validitas isi. Tahap validasi pertama adalah mengukur validitas isi materi pelajaran dalam buku sebagai pelengkap pembelajaran. Berdasarkan hasil perhitungan dengan formula Gregory maka didapat nilai content validity (CV) sebesar 0,94 . Nilai ini terkategori sangat tinggi. Dengan demikian dapat disimpulkan materi dalam buku sebagai pelengkap pembelajaran yang dikembangkan terkategori sangat valid.

Tahap validasi selanjutnya adalah pengujian validitas buku dengan instrumen LORI. Hasil yang diperoleh dihitung dengan rumus Lawshe. Ada empat indikator yang diukur, yaitu : kualitas isi, tujuan pembelajaran, umpan balik dan adaptasi dan motivasi. Hasil perhitungan menunjukan nilai CVR sebesar 1 yang berarti buku cerita yang dikembangkan valid. Setelah valid, selanjutnya dicari 
kategori validitas dengan mencari rataratanya.

Tabel 2. Kategori Validitas

\begin{tabular}{|c|c|c|c|}
\hline No. & Aspek & Nilai & Kategori \\
\hline 1. & Kualitas Isi & 4,65 & $\begin{array}{l}\text { Sangat } \\
\text { Tinggi }\end{array}$ \\
\hline 2. & $\begin{array}{l}\text { Tujuan } \\
\text { Pembelajaran }\end{array}$ & 4,75 & $\begin{array}{l}\text { Sangat } \\
\text { Tinggi }\end{array}$ \\
\hline 3. & $\begin{array}{l}\text { Umpan Balik } \\
\text { dan Adaptasi }\end{array}$ & 4,6 & $\begin{array}{l}\text { Sangat } \\
\text { Tinggi }\end{array}$ \\
\hline 4. & Motivasi & 4,8 & $\begin{array}{l}\text { Sangat } \\
\text { Tinggi }\end{array}$ \\
\hline \multicolumn{2}{|c|}{ Rata-rata } & 4,7 & $\begin{array}{l}\text { Sangat } \\
\text { Tinggi }\end{array}$ \\
\hline
\end{tabular}

Berdasarkan Tabel 2 maka dapat diketahui nilai untuk aspek kualitas isi buku sebagai pelengkap pembelajaran sebesar 4,65 dengan kategori sangat tinggi, aspek tujuan pembelajaran sebesar 4,75 dengan kategori sangat tinggi, aspek umpan balik dan adaptasi sebesar 4,6 dengan kategori sangat tinggi dan aspek motivasi sebesar 4,8 dengan kategori sangat tinggi.

Tahap selanjutnya adalah uji validitas isi buku sebagai media pembelajaran dengan menggunakan instrumen LORI. Data yang diperoleh kemudian dianalisis dengan formula Lawshe. Hasil analisis menunjukan nilai CVR 1 yang berarti buku cerita yang dikembangkan valid.

Tahap selanjutnya adalah menentukan tingkat validitas media pembelajaran. Hasil perhitungan dapat disajikan pada tabel berikut.

Tabel 3. Kriteria Validitas Media

\begin{tabular}{|c|c|c|c|}
\hline No. & Aspek & Nilai & Kategori \\
\hline 1. & $\begin{array}{l}\text { Desain } \\
\text { Presentasi }\end{array}$ & 4,8 & $\begin{array}{l}\text { Sangat } \\
\text { Tinggi }\end{array}$ \\
\hline 2. & $\begin{array}{l}\text { Interaksi } \\
\text { Pengguna }\end{array}$ & 4,47 & $\begin{array}{l}\text { Sangat } \\
\text { Tinggi }\end{array}$ \\
\hline 3. & Aksebilitas & 4,8 & $\begin{array}{l}\text { Sangat } \\
\text { Tinggi }\end{array}$ \\
\hline 4. & $\begin{array}{l}\text { Penggunaan } \\
\text { Kembali }\end{array}$ & 5 & $\begin{array}{l}\text { Sangat } \\
\text { Tinggi }\end{array}$ \\
\hline & $\begin{array}{l}\text { Memenuhi } \\
\text { standar }\end{array}$ & 4,8 & $\begin{array}{l}\text { Sangat } \\
\text { Tinggi }\end{array}$ \\
\hline \multicolumn{2}{|c|}{ Rata-rata } & 4,77 & $\begin{array}{l}\text { Sangat } \\
\text { Tinggi }\end{array}$ \\
\hline
\end{tabular}

Berdasarkan Tabel 3 maka dapat diketahui aspek desian mendapat nilai 4,8 dengan kategori sangat tinggi, aspek interaksi pengguna mendapat nilai 4,47 dengan kategori sangat tinggi, aspek aksebilitas mendapat nilai 4,8 dengan kategori sangat tinggi, aspek penggunaan kembali mendapat nilai 5 dengan kategori sangat tinggi dan aspek memenuhi standar mendapat nilai 4,8 dengan kategori sangat tinggi. Secara umum, nilai rata-rata aspek media adalah sebesar 4,77 dengan kategori sangat tinggi.

Berdasarkan hasil uji validitas, buku cerita yang dikembangkan terkategori valid. Berdasarkan kesesuaian antara materi pelajaran dalam buku dan tuntutan kurikulum, nilai validitas isi yang didapat sebesar 1. Ini menunjukan bahwa semua materi yang dituntut Kurikulum 2013 khususnya untuk siswa kelas $\mathrm{V}$ sudah sesuai dengan isi buku. Sugiharto dan Sitinjak (2006), validitas berhubungan dengan suatu peubah mengukur apa yang seharusnya diukur. Validitas dalam penelitian menyatakan derajat ketepatan alat ukur penelitian terhadap isi sebenarnya yang diukur. Ini berarti materi dalam buku cerita sudah secara tepat berisi materi yang dituntut kurikulum.

Materi dalam buku valid karena dalam pengembangan buku ajar maka terlebih dahulu dilakukan analisis pada Kurikulum 2013. Sebelum buku dibuat, terlebih dahulu dilakukan analisis materi yang ada dalam kurikulum. Selanjutnya, dilakukan penjabaran terhadap tema-tema yang ada. Dari analisis tema ini ditemukan adanya tuntutan materi berupa budaya nusantara yang termasuk di dalamnya adalah desa-desa unik. Dari sinilah kemudian dilakukan analisis lebih detail dan menjabarkan materi lebih rinci. Setelah itu dilakukan pengembangan buku cerita yang di dalamnya terkandung materi-materi yang dituntut. Langkahlangkah yang dilakukan ini sudah sesuai dengan langkah-langkah pengembangan buku menurut Dick dan Carey (2005). Dengan demikian, materi dalam buku cerita menjadi valid.

Analisis selanjutnya mengacu pada validitas produk secara menyeluruh dengan menggunakan instrumen LORI 
yang selanjutnya dianalisis dengan formula Lawshe. Hasil analisis menunjukan semua kriteria yang diharapkan dalam buku cerita terkategori valid. Ini berarti keempat aspek dalam LORI : kualitas isi, tujuan pembelajaran, umpan balik dan adaptasi dan motivasi telah dipenuhi dalam buku cerita yang dikembangkan. Kualitas buku yang baik sudah dapat dipenuhi oleh kualitas buku cerita yang dikembangkan (Neuman, 2007).

Pada aspek kualitas isi, kualitas materi menjadi hal utama yang disiapkan. Materi buku mengacu pada Desa Tenganan Dauh Tukad. Pemilihan desa ini didasarkan pada keunikan yang dimiliki. Keunikannya itu antara lain; Mesabatan Biu, Nulak Damar, Metekrok, Daha Nyambah, Mekare-Kare dari segi kebenaran, pengumpulan informasi tentang desa ini dilakukan secara langsung dengan menanyakan kepada tetua adat dan masyarakat di sana. Ide-ide yang terkandung dibuat seimbang antara narasi dan gambar-gambar sehingga buku menjadi menarik dan tidak membosankan. Dengan demikian, sesuai dengan tingkatan anak sekolah dasar. Menurut Notoatmodjo (2012), anak sekolah dasar menyukai sesuatu yang kongkret dan realistik. Dengan menambahkan gambargambar ilustrasi maka buku cerita menjadi lebih nyata dan realistik yang mana akhirnya membuat siswa menjadi menyukai buku yang dikembangkan.

Pada aspek tujuan pembelajaran, buku cerita yang dikembangkan mengacu pada Kurikulum 2013 dan silabus sekolah. Ibrahim (2003) menyatakan bahwa dasar penyusunan buku agar sesuai dengan tujuan pembelajaran adalah analisis kurikulum. Hal ini sesuai dengan langkahlangkah pengembangan buku cerita tang dikembangkan yang mana dimulai dari analisis Kurikulum 2013. Selain itu, pengembangan juga memperhatikan usia anak sekolah dasar. Dengan menyisipakan gambar-gambar ilustrasi maka anak akan mampu memahami buku secara kongkret dan realistik (Notoatmodjo, 2012).

Pada aspek umpan balik dan adaptasi, buku cerita mencakup dua mata pelajaran, PPKn dan Bahasa Indonesia. Ini berarti sesuai dengan pembelajaran tematik yang dilaksanakan di sekolah dasar. Sehingga dalam pembelajaran PPKn memberikan umpan balik kepada pembelajaran Bahasa Indonesia atau sebaliknya. Dengan demikian, guru hanya perlu menerapkan prinsip relevansi dalam menggunakan buku cerita yang dikembangkan (lif dan Sofan, 2010). Artinya, guru memilih dan memilah di bagian mana harus menyelipkan materi PPKn dan Bahasa Indonesia. Selain itu, guru juga dapat menggunakan model pembelajaran yang berbeda-beda dalam penerapan buku ini tergantung relavansinya dengan isi buku dan materi pelajaran.

Pada aspek motivasi, buku cerita yang dikembangkan mampu memotivasi siswa belajar karena sesuai dengan karakteristiks siswa sekolah dasar yang dikemukakan oleh Notoatmodjo (2012) yang menyatakan anak menyukai sesuatu yang kongkret dan realistik. Hal ini didukung oleh pendapat Heruman (2013) yang menyatakan bahwa pada masa sekolah dasar kemampuan yang tampak adalah kemampuan dalam proses berpikir untuk mengoperasikan kaidah-kaidah logika, meskipun masih terikat dengan objek yang bersifat konkret.

Selanjutnya, validitas buku sebagai media pembelajaran terkategori sangat valid. Pada sub aspek media pembelajaran seperti : aspek desian, aspek interaksi pengguna, aspek aksebilitas, aspek penggunaan dan aspek memenuhi standar juga terkategori sangat valid atau layak. Menurut Sudjana (2004), kevalidan menunjukan derajat pengukuran yang detail dan rinci dalam mengukur apa yang diukur. Dengan demikian, buku cerita yang dikembangkan sudah benar-benar memenuhi kriteria media pembelajaran yang baik.

Pada aspek desain, buku cerita menggunakan latar dan gambar-gambar yang berwarna-warni. Warna-warni dibuat semenarik mungkin agar siswa tertarik mempelajarinya. Selain itu, gambargambar dibuat dalam bentuk kartun dan berwarna-warni untuk mendukung narasi atau cerita yang dibuat. Dengan demikian, 
buku cerita yang dikembangkan mampu meningkatkan minat siswa untuk membaca atau mempelajarinya.

Pada aspek interaksi, buku dilengkapi dengan daftar isi sehingga mempermudah siswa dalam mencari materi yang diinginkan. Daftar isi dapat berperan sebagai navigasi dalam mencari materi yang diinginkan. Dari tampilan buku juga siswa dapat menebak dengan mudah apa saja yang dijelaskankarena didukung oleh gambar-gambar.

Pada aspek aksebilitas, buku cerita sangat mudah diakses karena tersedia dalam bentuk cetak maupun softcopy. Dengan demikian, siswa juga dapat mengaksesnya lewat smartphone atau laptop. Penyajian materi cerita juga bervariasi dari narasi, gambar-gambar, dan ada keterangan gambarnya. Ini akan mempermudah siswa dalam memahami atau mengakses pesan yang hendak disampaikan dalam buku.

Pada aspek penggunaan kembali, buku ini tidak hanya dapat digunakan oleh siswa. Akan tetapi, berbagai kalangan dapat mempergunakannya. Hal ini karena isi buku sifatnya umum dan tidak ada unsur menjelekan yang sifatnya SARA. Isi buku memang murni untuk memberikan pengetahuan tentang tradisi dan budaya yang ada pada masyarakat Desa Tenganan Dauh Tukad. Bagi orang Bali, ini akan menambah wawasan budaya tentang uniknya tradisi yang ada di Bali yang harus dilestarikan.

Pada aspek memenuhi standar, buku yang dikembangkan sudah memenuhi standar yang ditetapkan. Dalam proses pembuatannya, materi buku ini dimulai dari analisis Kurikulum untuk menetapkan tujuan. Langkah-langkah pengembangannya juga mengacu pada langkah-langkah model ADDIE yang sudah dipakai secara internasional. Dengan demikian, sangat kecil terjadi kesalahan dalam pengembangannya.

\section{Kepraktisan Buku Ajar}

Uji kepraktisan dilakukan oleh guru dan siswa. ada dua guru yang dilibatkan dalam uji kepraktisan ini. Hasilnya dapat disajikan pada tabel berikut.
Tabel 4. Hasil Uji Kepraktisan Guru

\begin{tabular}{|c|c|c|c|}
\hline No. & Aspek & Nilai & Kategori \\
\hline 1. & Ketertarikan & 4,67 & $\begin{array}{l}\text { Sangat } \\
\text { Praktis }\end{array}$ \\
\hline 2. & Materi & 4,5 & $\begin{array}{l}\text { Sangat } \\
\text { Praktis }\end{array}$ \\
\hline 3. & Bahasa & 4,84 & $\begin{array}{l}\text { Sangat } \\
\text { Praktis }\end{array}$ \\
\hline & Rata-rata & 4,67 & $\begin{array}{l}\text { Sangat } \\
\text { Praktis }\end{array}$ \\
\hline
\end{tabular}

Berdasarkan Tabel 4 maka dapat diketahui nilai aspek ketertarikan sebesar 4,67 dengan kategori sangat praktis, nilai aspek materi sebesar 4,5 dengan kategori sangat praktis dan nilai aspek bahasa sebesar 4,84 dengan kategori sangat praktis. Secara umum, rata-rata nilaikepraktisan sebesar 4,67 dengan kategori sangat praktis.

Setelah uji kepraktisan guru maka dilanjutkan dengan uji kepraktisan untuk siswa. Ada 25 siswa yang diminta responnya untuk menilai kepraktisan buku. Data dari keduapuluh lima siswa dapat disajikan pada Tabel 5.

Tabel 5. Ringkasan Uji Kepraktisan Produk (Siswa)

\begin{tabular}{crrl}
\hline No. & Aspek & Nilai & Kategori \\
\hline 1. & Ketertarikan & 4,82 & $\begin{array}{l}\text { Sangat } \\
\text { Praktis }\end{array}$ \\
2. & Materi & 4,71 & $\begin{array}{l}\text { Sangat } \\
\text { 3. }\end{array}$ \\
Bahasa & 4,77 & $\begin{array}{l}\text { Sangat } \\
\text { Sangat }\end{array}$ \\
Rata-rata & 4,77 & $\begin{array}{l}\text { Praktis } \\
\text { Sangat } \\
\text { Praktis }\end{array}$ \\
\hline
\end{tabular}

Berdasarkan Tabel 5 maka dapat diketahui nilai aspek ketertarikan sebesar 4,82 dengan kategori sangat praktis, nilai aspek materi sebesar 4,71 dengan kategori sangat praktis dan nilai aspek bahasa sebesar 4,77 dengan kategori sangat praktis. Secara umum,nilai ratarata kepraktisan buku sebesar 4,77 dengan kategori sangat tinggi.

Berdasarkan analisis, baik guru dan siswa menyatakan buku cerita yang dikembangkan terkategori sangat praktis. Semua aspek kepraktisan seperti : aspek ketertarikan, aspek materi dan aspek bahasa terkategori sangat praktis. Dengan 
demikian, produk yang dikembangkan mudah digunakan (Depdiknas, 2008).

$$
\text { Kepraktisan terkait dengan }
$$

kemudahan-kemudahan yang ada pada instrumen evaluasi baik dalam mempersiapkan, menggunakan, menginterpretasi/memperoleh hasil, maupun kemudahan dalam menyimpannya (Arikunto, 2012). Buku cerita yang dikembangkan dirancang sepraktis dan semudah mungkin agar tidak membebani siswa. hal itu dapat dilihat dari bahasa yang digunakan, pemaparan materi dan gambar-gambar yang mendukung buku. Kepraktisan juga ditunjang oleh adanya daftar isi yang memudahkan siswa menavigasi materi yang hendak dicari.

Pada aspek ketertarikan, tampilan buku dibuat dengan latar warna-warni dengan beraneka gambar yang menarik. Buku dirancang dengan kombinasi narasi dan gambar sehingga mudah digunakan atau dipelajari oleh peserta didik. Dengan variasi ini tentu siswa tidak akan bosan membaca buku cerita karena narasi selalu diperjelas dengan bantuan gambargambar pendukung. Hal ini mempermudah siswa melakukan atau memahami literasi budaya.

Pada aspek materi, buku berisi tentang kehidupan sehari-hari masyarakat Desa Tenganan Dauh Tukad. Buku juga berisi tradisi-tradisi yang masih dipertahankan seperti Mesabatan Biu, Nulak Damar, Metekrok, Daha Nyambah, Mekare-Kare. Tradisi tersebut dijelaskan secar sederhana agar mudah dipahami disamping juga ditambahkan gambargambar untuk membuatnya semakin mudah dipahami.

Pada aspek bahasa, kalimat yang digunakan adalah kalimat sederhana agar mudah dipahami. Hal ini mengingat buku utamanya digunakan oleh anak sekolah dasar. Dardjowidjoyo (2003) menyatakan bahwa bahasa adalah alat untukmenyampaikan pesan sehingga agar pesan sampai dengan baik maka bahasa yang digunakan juga harus baik. Bahasa yang dirancang memang agar siswa usia sekolah dasar mudah memahami sehingga pesan dalam buku dapat dicapai oleh siswa.

\section{Efektivitas Buku Ajar}

Uji efektivitas produk dilakukan dengan mengujicobakan produk pada siswa. Siswa terlebih dahulu diajar dengan menggunakan buku yang dikembangkan. Selanjutnya, siswa diberikan tes untuk mengetahui daya serap siswa. Tes dilakukan terhadap 25 siswa. Hasil Uji efektivitas dapat disajikan pada Tabel 6.

Tabel 6. Hasil Uji Efektivitas

\begin{tabular}{|c|c|c|c|c|}
\hline $\begin{array}{l}\mathrm{N} \\
\mathrm{O}\end{array}$ & $\begin{array}{l}\text { Mata } \\
\text { Pelajara } \\
n\end{array}$ & $\begin{array}{l}\text { Ketun } \\
\text { tasan } \\
\text { Minim } \\
\text { al }\end{array}$ & $\begin{array}{l}\text { Ketun } \\
\text { tasan }\end{array}$ & $\begin{array}{l}\text { Keputu } \\
\text { san }\end{array}$ \\
\hline 1 & PPKn & $85 \%$ & $88 \%$ & Efektif \\
\hline 2 & $\begin{array}{l}\text { Bahasa } \\
\text { Indonesi } \\
\text { a }\end{array}$ & $85 \%$ & $96 \%$ & Efektif \\
\hline
\end{tabular}

Berdasarkan Tabel 6 maka dapat diketahui ketuntasan siswa untuk mata pelajaran PPKn adalah $88 \%$ dan ketuntasan untuk mata pelajaran Bahasa Indonesia adalah 96\%. Keduanya lebih tinggi daripada ketuntasan minimal yang ditetapkan yaitu $85 \%$. Dengan demikian, produk yang dikembangkan berupa buku cerita tentang Desa Tenganan Dauh Tukad terkategori efektif.

Hasil penelitian ini relevan dengan penelitian yang dilakukan oleh Wirawan (2018). Penelitian ini mengembangkan buku cerita anak tema Hidup Rukun untuk Kelas II Sekolah Dasar. Hasil penelitian menunjukkan bahwa buku cerita berjudul " I Semangah dan temanya"efektif digunakan sebagai buku pendamping buku Kurikulum 2013 yang digunakan dalam proses pembelajaran di kelas II tema Hidup Rukun.

Hasil ini juga relevan dengan penelitian Putra (2018). Penelitian ini mengembangkan buku cerita anak berdasarkan muatan sikap dan muatan pembelajaran pada subtema Ayo Cintai Lingkungan Kurikulum 2013, dengan menginsersi budaya lokal yang relevan. Berdasarkan hasil penilaian para ahli, diperoleh kualitas dan kesesuaian buku cerita, diperoleh efektivitas penggunaan buku cerita "Lembu Peteng" terhadap sikap siswa sebesar 12,29 tergolong sangat efektif; terhadap minat baca siswa 
sebesar 13,66 tergolong sangat efektif; dan terhadap hasil belajar siswa sebesar 7,44 tergolong sangat efektif.

\section{PENUTUP}

Berdasarkan hasil analisis secara deskriptif maka ada tiga simpulan yang dibuat, yaitu: 1) produk berupa buku cerita valid baik secara materi maupun media, 2) produk berupa buku cerita sangat praktis dan 3) produk berupa buku cerita terkategori efektif. Ini berarti buku cerita yang dikembangkan layak digunakan sebagai pelengkap buku paket pelajaran yang digunakan di sekolah.

Berdasarkan simpulan yang dibuat maka ada beberapa saran yang diberikan kepada siswa dan guru. Siswa disarankan untuk menggunakan buku cerita tentang desa Tenganan Dauh Tukad dengan baik selama proses pembelajaran karena materi terkandung di dalamnya sesuai dengan materi isi kurikulum. Guru disarankan untuk menggunakan buku yang dikembangkan ini sebagai pendamping buku paket dari pemerintah. Guru bisa menggunakannya sesuai dengan kebutuhan materi di lapangan. Selain itu, guru disarankan untuk mengarahkan siswa membaca buku ini karena mengandung unsur-unsur budaya asli dan unik di Bali. Dengan demikian, siswa mendapat pengetahuan tentang budayanya.

\section{DAFTAR RUJUKAN}

Adelina, Novilia dkk. 2016. Tema 5 Pengalamanku Buku Tematik Terpadu Kurikulum 2013 : Buku Guru SD /MI Kelas 1. Pusat Kurikulum dan Perbukuan Kemendikbud.

Amri, Sofan. lif Khoiru Ahmadi. 2010. Proses Pembelajaran Kreatif dan Inovatif Dalam Kelas: Metode, Landasan Teoritis-Praktis dan Penerapannya. Jakarta: PT. Prestasi Pustakaraya

Arikunto, Suharsimi (Ed). 2012. DasarDasar Evaluasi Pendidikan. Jakarta: Bumi Aksara.
Arief S Sadiman, dkk. 2007. Media Pendidikan. Jakarta: PT. Raja Grafindo Persada.

Arsyad, Ashar.2002. Media Pembelajaran. Jakarta: Raja Grasindo Persada Candiasa. 2010. Statistik Univariat dan Bivariat Disertai Aplikasi SPSS. Singaraja: Unit Penerbitan Universitas Pendidikan Ganesha.

Azhar Arsyad. (2004). Media Pembelajaran. Jakarta : PT. Raja Grafindo Persada

Dardjowidjojo, Soedjono. 2003. Psikolinguistik: Pemahaman Bahasa Manusia. Jakarta: Yayasan Obor Indonesia

Dick, W and L. Carey, J. O. Carey. 2005. The systematic Design of Instruction. New York : Logman.

Dimyati dan Mudjiono. 2002. Belajar dan Pembelajaran. Jakarta: Departemen Pendidikan \& Kebudayaan dengan Rineka Cipta

Depdiknas, 2008. Kurikulum Tingkat Satuan Pendidikan. Jakarta. Dikmenum. Depdiknas

Gregory, J. Robert. 2010. Tes Psikologi, Sejarah, Prinsip dan Aplikasi. Jakarta: Erlangga.

Heruman, 2013. Model Pembelajaran Matematika di Sekolah Dasar. Bandung: PT REMAJA ROSDAKARYA

Ibrahim, dkk. 2003. Perencanaan Pengajaran. Bandung : PT. Remaja Rosdakarya.

Mardapi, Djemari. 2008. Teknik Penyusunan Instrumen Tes dan Non Tes. Jogjakarta: Mitra Cendika Press.

Mulyasa, E. 2013. Pengembangan dan Implementasi Kurikulum 2013. Bandung: PT. Remaja Rosdakarya.

Neuman, W. L. 2007. Basic of Social Research: qualitative and quantitative approach. Boston, 
United State of America: Pearson Education, Inc.

Notoatmodjo . 2012. Metode Penelitian Kesehatan. Jakarta : Rineka Cipta

Peraturan Menteri Pendidikan dan Kebudayaan Nomor 22 Tahun 2016Tentang Standar ProsesPendidikan Dasar dan Menengah

Peraturan Menteri Pendidikan dan Kebudayaan Nomor 23 Tahun 2016 Tentang Standar Penilaian Pendidikan Dasar dan Menengah

Peraturan Menteri Pendidikan dan Kebudayaan Nomor 64 Tahun 2013 Tentang Standar Isi Pendidikan Dasar dan Menengah

Sudjana, Nana. 2004. Dasar-dasar Proses Belajar Mengajar. Bandung :Sinar Baru Algensido Offset.

Sugiarto, Sitinjak. (2006). Lisrel. Edisi Pertama. Cetakan Pertama Yogyakarta: Penerbit Graha IImu.

Wigianto. 2015. "Pengembangan Buku Cerita Bergambar Pendidikan Karakter Tanggung Jawab Untuk Peserta Didik Sekolah Dasar". EJournal, Fakultas Bahasa Dan Seni. Universitas Negeri Jogjakarta. Tersedia pada https://osf.io/tjc32/download

(Diakses tanggal 19 Maret 2021). 